\title{
Palaeoenvironmental reconstruction on the basis of Quaternary palaeo dune sequences on Fuerteventura
}

\section{Christopher-Bastian Roettig}

Department of Geography, Faculty of Environmental Science, Dresden University of Technology, Dresden, Germany

Correspondence: Christopher-Bastian Roettig (christopher-bastian.roettig@tu-dresden.de)

Relevant dates: $\quad$ Received: 24 February 2020 - Revised: 18 May 202 - Accepted: 22 July 2020 Published: 13 October 2020

How to cite: $\quad$ Roettig, C.-B.: Palaeoenvironmental reconstruction on the basis of Quaternary palaeo dune sequences on Fuerteventura, E\&G Quaternary Sci. J., 69, 161-163, https://doi.org/10.5194/egqsj-69-161-2020, 2020.

Supervisor: Dominik Faust

Dissertation online:

https://nbn-resolving.org/urn:nbn:de:bsz:14-qucosa2-

358871

The volcanic origin of the Canarian Archipelago widely determines the landscape of these islands. Partially near coastal areas the volcanic rocks are covered by dune fields. The eastern Canary Islands show the largest areas of sand deposits. On northern Fuerteventura sandpits and deep incised gully systems allow broader insight into generations of these archives. The dune material originates from the shallow shelf. Hence, the mineral composition is dominated by calcite and aragonite. The outcrops show the layering of several generations of biogenic carbonate sands which are separated by palaeosurfaces. These surfaces suggest soil-forming processes with their (often) reddish colour. Generally, the occurrence of several palaeosurfaces promises a high potential of those Quaternary dune archives on northern Fuerteventura. Former studies focussed on just few quarries being situated in close distances. Differing formation concepts and contradicting chronologies (Middle to Late Pleistocene versus Late Pleistocene) suggest the need for further investigation of landward palaeo dune sections, resulting in a German Research Foundation-funded project (FA 239/18-1) with regard to palaeo dune sequences within the catchments of two barrancos on northern Fuerteventura. Firstly, the project called for defining representative sections of the two catchments for the purpose of working out a correlation and deducing a standard profile; both should be based on stratigraphic findings. Luminescence dating shall contribute to finally establishing a chronostratigraphy. Besides the carbonate sands, the dune archives are influenced by the imprint of volcanic material (tephra, lapilli, and basaltic rock) and Saharan dust. Generally, the archives' composition and appearance raise several further questions. Are periods of surface formation dependent on reduced sand supply or on changes in climatic conditions? Which soil forming processes contribute to the characteristics of palaeosurface layers? What is the influence of Saharan dust? As dating of lava flows on northern Fuerteventura revealed Middle to Late Pleistocene ages, a further question refers to the relationship between dune formation and volcanic activity.

Mainly deduced from findings in the field but also by use of grain size distribution, elemental composition, content of $\mathrm{CaCO}_{3}$, determination of $\mathrm{Fe}_{\mathrm{d}}$ (pedogenic iron), measurements of rock magnetic parameters, analyses of gastropod associations, micromorphological analyses, determination of quartz content via automatic static image analysis with a Malvern Morphologi G3-ID, XRD analyses, and IRSL dating, this thesis provides a chronostratigraphy of palaeo dune archives of northern Fuerteventura deduced from a correlation of sections close to the western coast and sections close to the eastern coast. The derived standard profile shows 


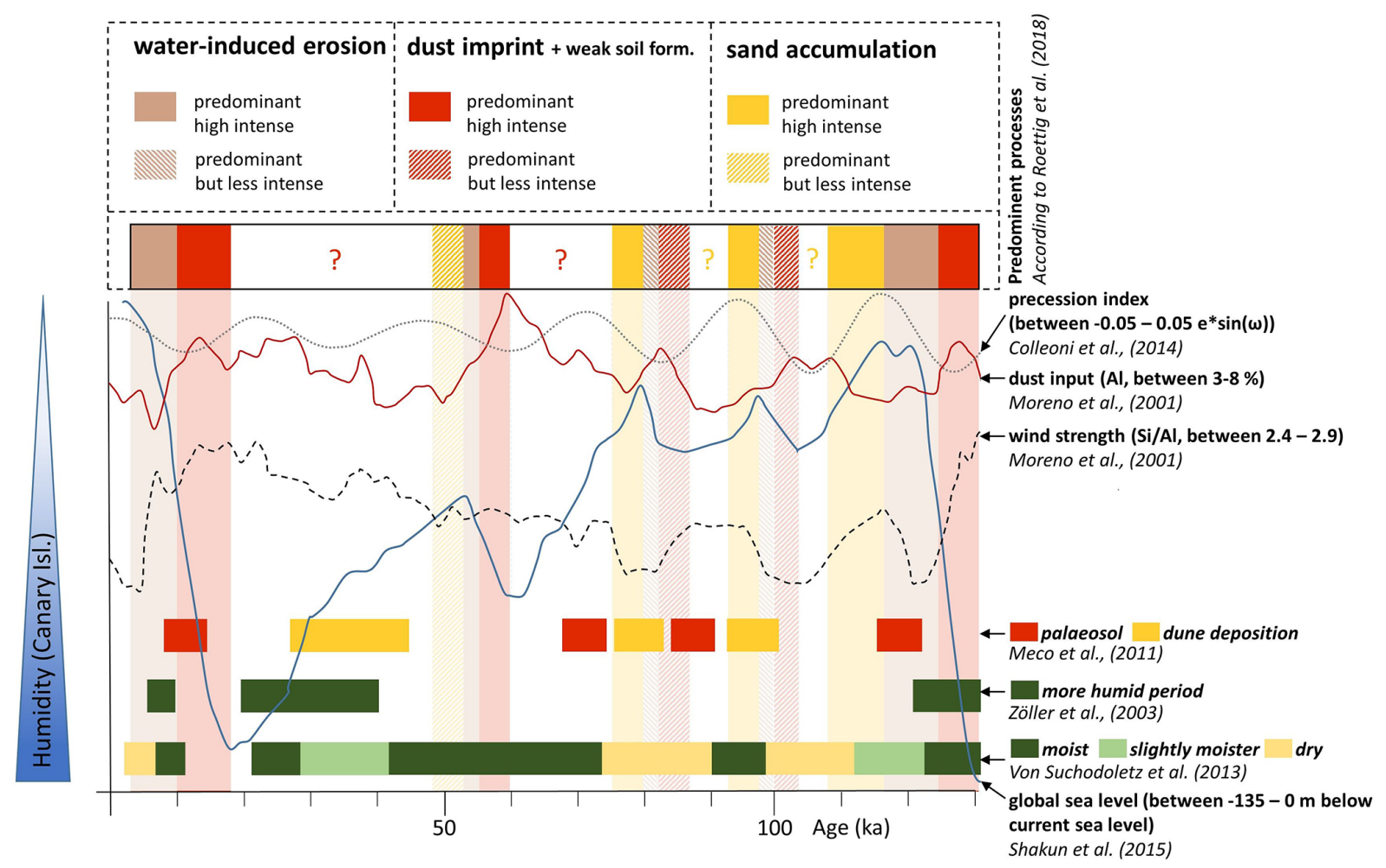

Figure 1. Data of Canarian archives on the backdrop of the conceptual approach according to Roettig et al. (2019), modified.

15 units divided into five main sequences. These five sequences mainly differ in sand supply and accumulation, in changing humidity, and in imprint of volcanic activity. The chronostratigraphy dates back to about $450 \mathrm{ka}$. Generally, the archives are very site-specific, because features of a stratigraphic layer often change within close distances, depending on connectivity to erosion pathways and distance to sand sources. Micromorphological analyses indicate soil forming processes which are restricted to de- and recalcification and recrystallisation of iron and manganese. Ultimately, the palaeosurfaces are primarily dominated by the characteristics of Saharan dust (silt dominated, yellow to red in colour, containing hematite and goethite). The archives indicate a cyclicity of predominant processes, starting with (i) sand accumulation, followed by (ii) dust accumulation and weak soil formation, leading to (iii) water-induced relocation. On the basis of this cyclicity a conceptual approach of the archives' relationship with changes in sea level could be drawn (Fig. 1). We assume highest sand supply during starting regression after sea level maxima. With dropping sea level, the distance between the studied sites and the sand source area (which are the gradually exposed shallow shelf areas) increases, leading to reduced sand accumulation. Starting transgression at the end of glacials suggests the lowest potential of sand accumulation. Furthermore, the concept is based on the assumption that with lower sea levels, more precipitation can reach the Canary Islands. Deduced from periods of lowest potential of sand accumulation in combination with periods of increased precipitation, best conditions for predominant dust accumulation and in situ processes should be given at terminations. Generally, prevalence of palaeosurface formation is related to transgression periods. These periods are in good agreement with increased dust supply, which, in turn, seems to be affected by precession minima (according to Moreno et al., 2001). The predominance of dust accumulation and in situ processes causes the fining of sediments, leading to reduced morphological resistance and, finally, water-induced relocation. Ultimately, site-specific sand availability seems to determine whether surfaces are exposed for longer durations, whereas the availability of precipitation (and dust) suggests determining the intensity of surface formation.

The studied sections indicate a strong relationship with local volcanic activity because lava flows are able to cut off sand pathways and cover former sand source areas. In combination with dated lava flows the findings point to three different periods of volcanic activity which ceased the sand supply gradually: a first period around $180-170 \mathrm{ka}$, a next period around $135 \mathrm{ka}$, and a third period after $100 \mathrm{ka}$ but the latest around $50 \mathrm{ka}$, which, finally, completely stopped the sand supply. Regarding the northern part of Fuerteventura, the latest period has so far not been described. 
Data availability. The data are publicly available via the thesis (dissertation online) and references therein.

Competing interests. The author declares that there is no conflict of interest.

Financial support. The article processing charge was funded by the Quaternary scientific community, as represented by the host institution of EGQSJ, the German Quaternary Association (DEUQUA) and the German Research Foundation (DFG) (FA 239/18-1).

Review statement. This paper was edited by Christopher Lüthgens and reviewed by one anonymous referee.

\section{References}

Colleoni, F., Masina, S., Cherchi, A., Navarra, A., Ritz, C., Peyaud, V., and Otto-Bliesner, B.: Modeling Northern Hemisphere icesheet distribution during MIS 5 and MIS 7 glacial inceptions, Clim. Past, 10, 269-291, https://doi.org/10.5194/cp-10269-2014, 2014.

Meco, J., Muhs, D. R., Fontugne, M., Ramos, A. J. G., Lomoschitz, A., and Patterson, D.: Late Pliocene and Quaternary Eurasian locust infestations in the Canary Archipelago, Lethaia, 44, 440$454,2011$.
Moreno, A., Targarona, J., Henderiks, J., Canals, M., Freudenthal, T., and Meggers, H.: Orbital forcing of dust supply to the North Canary Basin over the last $250 \mathrm{kyr}$, Quaternary Sci. Rev., 20, 1327-1339, 2001.

Roettig, C.-B., Varga, G., Sauer, D., Kolb, T., Wolf, D., Makowski, V., Recio Espejo, J. M., Zöller, L., and Faust, D.: Characteristics, nature, and formation of palaeosurfaces within dunes on Fuerteventura, Quaternary Res., 91, 4-23, 2019.

Shakun, J. D., Leab, D. W., Lisiecki, L. E., and Raymo, M. E.: An 800-kyr record of global surface ocean $\delta^{18} \mathrm{O}$ and implications for ice volume-temperature coupling, Earth Planet. Sc. Lett., 426, 58-68, 2015.

Von Suchodoletz, H., Zöller, L., Hilgers, A., Radtke, U., and Faust, D.: Vegas and dune-palaeosoil-sequences - two different palaeoenvirnmental archives on the Eastern Canary Islands, in: Climate change perspectives from the Atlantic: past, present and future, edited by: Fernández-Palacios, J. M., de Nascimento, L., Hernández, J. C., Clemente, S., González, A., and DíazGonzález, J. P., Servicio de Publicaciones, Universidad de La Laguna de Tenerife, Tenerife, 249-264, 2013.

Zöller, L., von Suchodoletz, H., and Küster, N.: Geoarchaeological and chronometrical evidence of early human occupation on Lanzarote (Canary Islands), Quaternary Sci. Rev., 22, 1299-1307, 2003. 